\title{
Evaluating the impact of financing structure decisions on FTTH deployment. A comparison between New Zealand and Europe.
}

Marlies Van der Wee, Fernando Beltran, Sofie Verbrugge

\begin{abstract}
From both academic research as well as empirical evidence, it is apparent that the ever increasing demand for higher bandwidth and more reliable networks will drive the worldwide deployment of Next-Generation Access (NGA) networks. The paths followed to achieve this goal markedly vary, however, across different countries. The nationwide Fibre-to-the-Home (FTTH) investment strategy by the government of New Zealand, also known as the Ultra-Fast Broadband (UFB) initiative, alongside an open access obligation, contrasts sharply with the local European initiatives for NGA deployments. It is therefore timely to compare the UFB network in New Zealand with a range of relevant European cases.

The present paper develops an analytical framework that builds upon technology, policy, and market aspects and their interactions allowing for a clear mapping of the incentives, goals and actions of the different players in the field. By applying this framework to selected FTTH deployment cases, while taking account of geographical characteristics and market structures, among others, this work draws relevant conclusions about the impact of investment decisions on main case performance criteria such as coverage and uptake.
\end{abstract}

Keywords - Fibre-to-the-Home, investment in broadband, Public-Private Partnership, New Zealand, Europe

\section{Introduction}

The current trends in increasing demand for faster and more reliable connections stimulate the deployment of Next-Generation Access (NGA) networks. However, deploying new infrastructure, especially Fibre-to-the-Home (FTTH), requires significant levels of investment. Different economic investment models are currently being used worldwide to steer the deployments, ranging from no government intervention (fully private deployment), to a collaboration of private companies and public actors in a Public-Private Partnership (PPP), to public procurement or even fully governmentdriven and publicly-operated rollout. Furthermore, variants in scale of deployment can be identified: small rural town initiatives, regional solutions or nationwide projects.

The nationwide PPP Ultra-Fast Broadband (UFB) network initiated by the government of New Zealand contrasts sharply with the European local initiatives, which use mixed models of investment and are subject to strong regulation. A common aspect of both types of deployment is the alignment of goals by both public and private parties when working together under a PPP. Whereas the public partners (governments and local authorities) focus on getting as much from e-services as possible to 
the public institutions and end-customers, private companies want to satisfy their stakeholders by increasing profits through innovative services and competitive offers.

The cases identified in this paper not only cover a large range in the scale of deployment but insightfully cover the spectrum of public and private modes of participation in infrastructure deployment. They also find themselves on different stages of development with one case already fully operational for several years and another being in a very early phase of construction. It is desirable to arrive to observations that reveal the relationship between indicators of goal achievement and the characteristics of the investment vehicles. For example, empirically finding a relationship between the estimated amounts of risk shifted onto a private partner and the speed of deployment or any other indicator that quantifies the extent to which the targeted population is indeed being reached by fibre connections. However neither the number of observations nor the completeness of them would be amenable for developing an accurate statistical model. This paper has opted instead for finding a common framework for effective comparison, and possibly robust assessment, of the New Zealand nationwide fibre initiative and the European regional projects.

A technology-policy-market interaction framework is proposed that allows for a clear mapping of the incentives, goals and actions of the different players in the field (Melody, 2013). Looking on the economic investment model used from a multi-domain perspective (technology, policy and the market) broadens the view and allows reaching richer conclusions. This framework is applied to the following FTTH deployment cases: New Zealand's UFB, the publicly-owned dark fibre infrastructure provider Stokab in Stockholm (Sweden), a PPP under the Market Economy Investors Principle in Amsterdam (the Netherlands), and a private initiative undertaken by the different providers, mainly the incumbent, in Portugal. These cases were chosen because they represent different types of investment mechanisms and so they cover the range of investment models of interest.

The goal of this paper is to investigate, on a case-to-case basis, the links between the choice of investment model, including the level of public and private involvement, and several factors that speak about the success of a FTTH deployment. Thus the paper identifies the drivers for investment in each case and the investment mechanism. Then it looks into indicators relating to the main goals of the infrastructure deployment such as coverage and speed of deployment. As an important factor in the creation of incentives for private investment the paper also compares the type and amount of risk shared between partners.

After providing an introduction to PPPs and government intervention in broadband deployment in section 2, the technology, policy and market aspects are brought together in the interaction framework presented in section 3. The UFB programme in New Zealand is described in section 4, while section 5 applies the framework to three cases in Europe. Comparison criteria are used in section 6 to highlight the commonalities and differences in how those cases have performed thus far. Conclusions and recommendations are formulated in Section 7.

\section{PPPs and government intervention in BB deployment}

This section presents a definition of the mechanism that allows a government to enter a partnership to undertake an infrastructure construction project and an overview of the range of options that a government may rely upon when private participation is needed or preferred. In addition it 
introduces the concepts key to the assessment of the success of the kind of FTHH deployments examined here.

Although the need for FTTH networks has been shown and demand has been proven (Van der Wee, 2014), investment incentives for private operators to upgrade their networks to fibre-based have been absent, and as such some governments have tried alternative financial initiatives. These initiatives could include both private and public investment (financing structure), as well as different forms of "authority aid", mainly in the form of laws or regulations. In this paper, we will mainly focus on the choice for and impact of the financing structure. To inform the analysis and make it relevant to policy makers, the paper also links to relevant regulatory decisions where useful.

Government involvement in fibre network deployment can be explained by looking into the PublicPrivate Partnership (PPP) mechanism adopted in New Zealand and other parts of the world. The latter is one of a range of mechanisms by which an infrastructure project can be financially structured.

\subsection{Forms of public and private participation in infrastructure project}

Figure 1 gives an overview of the five main financing structures that can be identified for large projects (not limited to telecommunication networks deployments). They range from $100 \%$ public investment to $100 \%$ private investment:

- In the complete government production and delivery, a public institution is responsible for the planning, deployment and maintenance of the project.

- When a public party invests the funds, but outsources the execution (and possible operations or maintenance) of the project to private partners, the investments mechanism is referred to as public procurement.

- A Public-Private Partnership (PPP) is characterized by both public and private investment, and hence, both public and private risk. This investment mechanism will be described in more detail in the next paragraph.

- The fourth mechanism is a concession, frequently also referred to as a tender. In this case, the public party grants a private partner the rights to deploy and operate an infrastructure (or to execute and maintain a project). The private partner relies on revenues from the project's users, to recoup its investment. Notice that, in this case, the private investment (and risk) is higher than in the case of a PPP.

- Privatisation is the final financing structure, and involves no public investment. 


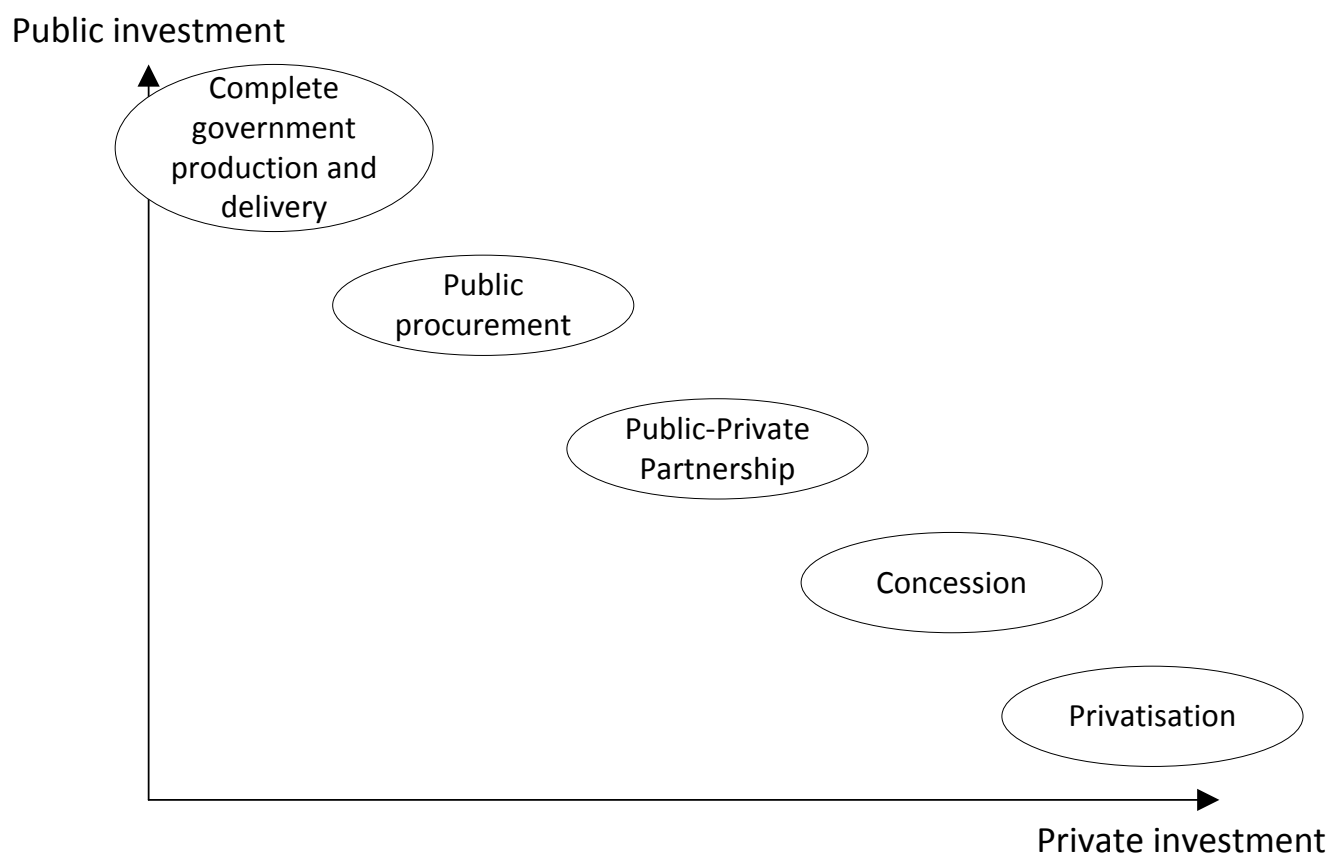

Figure 1: Overview of types of public private collaboration possibilities (Adapted from OECD, 2008)

Depending on the level of government involvement, different legal frameworks allow or forbid some of these investment mechanisms. In general, competition law dictates that government intervention should only be allowed in cases where the market is not delivering the right quality and/or quantity. Lemstra and Groenewegen argue that governments only should intervene in case of a market failure, where it has been proven that the private market players have tried to correct the failure without any result (Lemstra and Groenewegen, 2009). In this situation, the authorities can use competition law to correct the abuse of market power, they can set specific regulation on standards (quality of service) or impose price corrections through the use of taxes and subsidies.

\subsection{Defining PPPs in the context of broadband expansion}

A PPP finds the middle point between public and private investment, and is defined as a contract between an authority (e.g. the national government or a municipality) and one or more private partners (OECD, 2008). By including both public and private money, the alignment of objectives can be assured: the service-delivery objective of the public parties along with the profit-maximization of the private parties (Fourie en Burger, 2000), making the agreement mutually beneficial and economical (Tylee, 2013). Another approach towards PPPs is seeing it as lying between the government and the market (Howell, 2013), with the government representing centralized control of transactions and the market representing decentralized control. Because of this, PPP seems to be favoured as Howell argues that the "most efficient organization is always within institutions positioned somewhere along the continuum between the market and the government". The decision on where to draw the line between the government and the market depends then on transaction costs, which represent the added or reduced cost of trading on or off the production price.

One key aspect that differentiates PPPs from traditional procurement models is the fact that the agreement involves a risk-transfer mechanism; i.e. the private partners in a PPP must bear an agreed share of the risk, and as such are incentivized to deliver the product as efficiently as possible. Thus 
PPPs are expected to deliver higher value-for-money by achieving the same goals as public procurement models, but at lower cost.

On the other hand, the involvement of public money is also key, and provides the main differentiator to privatised projects. Public money ensures that government can impose their coverage targets and can provide a type of "subsidy" to ensure the economic viability of the entire project.

The OECD states that a well-established broadband deployment PPP must balance out four factors: connectivity (in terms of universal service), competition (by requiring enough private risk), innovation (as the deployment of a new network generates opportunities on services and applications level) and social benefit (benefit for other sectors of society) (OECD, 2009). To ensure this, four elements should be included in the mechanism: the clear and long-term relationship between public and private partners, private equity as part of the funding, main objectives defined by the public actor, while implementation decisions left to the private one(s), and clear sharing of risk (Falch and Henten, 2010).

\subsection{Assessing the success of deployments}

Although the previous paragraphs may have led to believe that a PPP might be the best approach to every large-scale project, it is through assessing agreed measurements of performance that such a claim should be validated. Also, in one way or another, PPP includes government intervention in fibre deployment and will consequently distort the course of action (or inaction) that a completely market-based approach would follow.

The most straightforward way to evaluate the success of a project is to verify to what extent its goals and targets have been reached upon completion. As a PPP involves public investment, one important argument is that the funds are used in a right way, i.e. that the project is finished on time and within budget. In an early stage of a FTTH deployment, which is the stage the UFB in New Zealand is in today, these indicators are most probably the only ones that can be used to evaluate the success of the PPP, as the project is not yet mature enough to draw conclusions about uptake or social benefits.

On the other side, conclusions can be drawn about the road towards deciding for a certain investment mechanism. Here, the paper aims at identifying the relation between the driver, amount of risk transferred and investment mechanisms. Risk transfer is inherently linked to PPPs, as part of the investment risk should be borne by the private party. Beltrán argues that "it is the degree of risk transfer from the government onto the private party that determines the real nature of the contractual relationship between them" (Beltrán, 2013). The initiative driver, on the other side, provides a second source of input conditions for making the decision of choice of investment mechanism. Three main drivers have been identified by Cave (2012): competition, which can be linked to a more privately-oriented investment; public contract, in which societal objectives lead to the government taking up the leading role; and regulation, in which authorities can force the current operator to deploy, using subsidies in a public procurement model or shared risk in a PPP.

Where government participation is present, the drivers for investment are grounded on expectations of social return and economic benefit in the medium-term. Stakeholders in the 
deployment of a FTTH network want to see construction deadlines met and targeted households reached. The national and local projects analysed here did set up ambitious goals in terms of the time to finish the deployment and the number of households/businesses whereby fibre would pass. Coverage (actual and target) is then one indicator of the degree of success in meeting the goals.

It has also been recognised that private investment would not be able to provide a high-speed infrastructure before a desired point in time. The timing is a pressing factor that has to do with the way government perceives the position of their economies in the world's GDP rankings. The proven positive correlation between broadband expansion and increase of the economic activity and its products has served as a foundational argument to the state-level broadband policies (Kim, Kelly and Raja, 2009). Therefore speed of deployment (relative to targets) is another indicator to be regarded in this paper's comparison.

In this paper, we will link the Technology-Policy-Market interaction framework used for analysing the cases (see section 3 for a more detailed description) to both factors of characterization and indicators of performance, to evaluate the success of PPP in the deployment of fibre access networks.

\section{Technology - Policy - Market interaction framework}

Although the development of new products and services is facilitated by technology, they only make it into the market when demand for them has built up. Similarly, if market dynamics do not provide enough incentives for operators to, for instance, adopt new technologies and upgrade the networks, government intervention in the form of acts, laws or regulation could be justified. Finally, markets don't develop or evolve independent from policy decisions or technological innovations.

As such, the studied fibre deployment cases should be investigated within a framework that uses these three domains: technology, policy and market. Following the research by Melody (2013), who identified the impact of technology through applications, the impact of markets through services and the impacts of policy through the regulations, this paper uses the interaction between technology, policy and the market to describe how decisions on the financing structure of the new deployments impact their performance as measured by a variety of criteria both in New Zealand and European cases (Figure 2). 


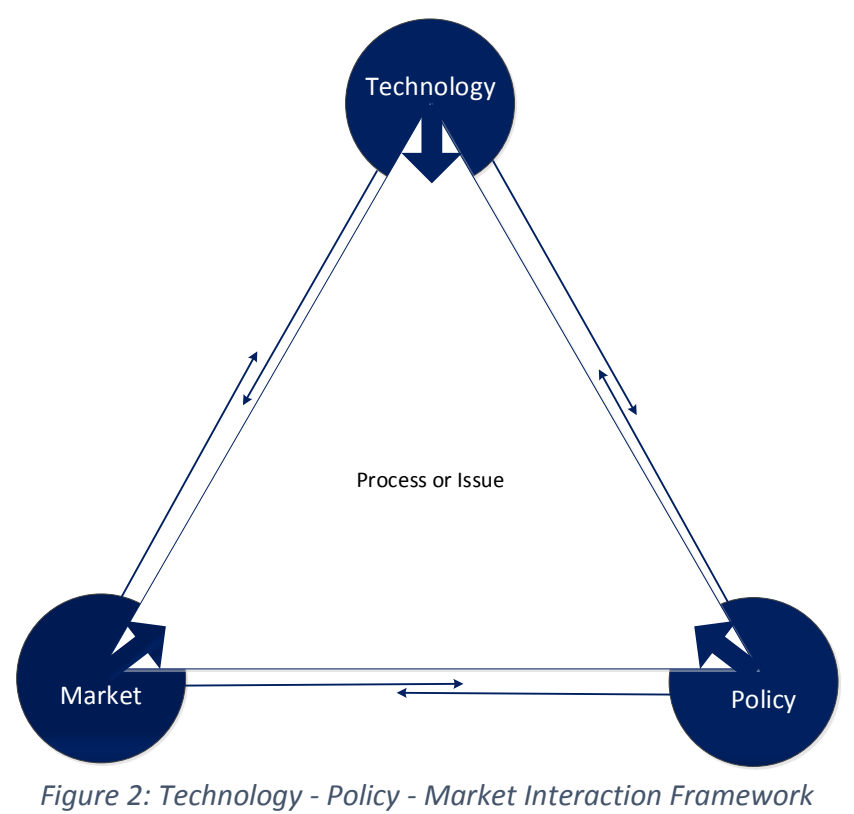

The technology pillar groups all innovations, both in network upgrades and applications and services development, not limited to the telecom sector only. Within the scope of FTTH networks, it includes the choice of network topology (Point-to-Point P2P or Point-to-Multipoint P2MP), network architecture (Active Ethernet or Gigabit Passive Optical Network (GPON)), deployment method (aerial or buried), equipment innovations (e.g. on ONT or OLT side), etc.

Policy comprises all laws, guidelines, regulations and directives that impact the deployment of FTTH either directly or indirectly. They can be made on local, regional, national or international level. Examples include wholesale price regulation, competition law, Digital Agenda guidelines, etc.

The third and final pillar, the market, combines all commercial and strategic decisions, both by the end-user and by the industry players itself. Examples include the customer's decision to take up on a fibre connection, the RSP's service offers in terms of speeds and caps and the FTTH platform's wholesale tariff structure.

By focusing on the decisions made by actors in the three different pillars of the framework, the effect of their decisions on the other pillars can be studied, and possible interaction identified. Applying the framework on the financial decisive phase of different FTTH initiatives across New Zealand and Europe, allows analysing both the drivers behind implementing a certain investment model, as well as the success of that model on the specific initiative.

\section{A nationwide public-private partnership in New Zealand}

New Zealand government committed NZD \$1.5 billion to a FTHH deployment aimed to reach $75 \%$ of households and businesses, an initiative known as the Ultra-Fast Broadband network (Sadowski, Howell and Nucciarelli, 2013; CFH, 2013; Beltrán, 2012). The remainder is to be served mainly by the Rural Broadband Initiative, through investment in wireless connectivity and VDSL connections, a result of Telecom NZ's cabinetisation programme in the mid to late 2000s. Crown Fibre Holdings (CFH), a publicly-owned company, was created to manage the investment funds. A tender process saw four private companies win shares in the total investment funds to deploy the UFB. The four partnerships so created are known as Local Fibre Companies (LFCS) and will eventually own and operate the network on a wholesale-only basis. They are: NorthPower Fibre, UltraFast Fibre, Enable and Chorus; the latter was established from a demerger of Telecom New Zealand into Chorus (the 
wholesale company owning the network) and Telecom Retail (now Telecom, providing the retail services which include mobile).

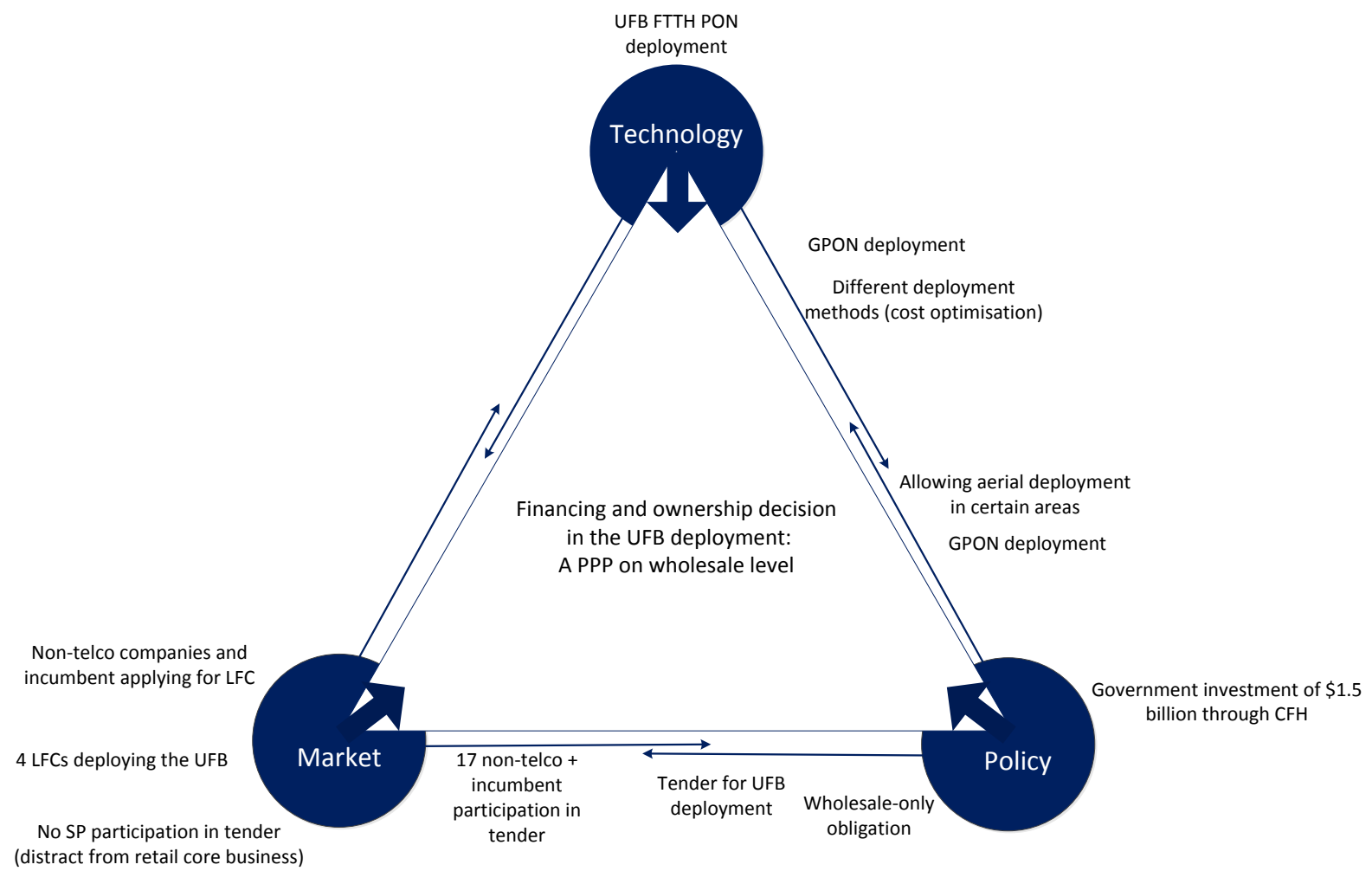

Figure 3: PPP in New Zealand

The PPP was structured in two different models: the "funds-recycling" model with the LFCs, and the "investment" model with Chorus. The contract with the LFCs is based on the recycling of capital in which CFH funds the fibre passing (the dark fibre, Layer 1 network deployed along the streets) and when a customer shows interest to subscribe to fibre services the LFC then funds the drop section (from the street to the customer's premises) and a subscription-based retail commercial relation starts between the customer and a retail service provider, which in turn pays for capacity to the LFC at wholesale prices. This income can then be used by the LFC to buy a share in the UFB network (so far owned by CFH), gradually acquiring ownership of the entire network. CFH in turn can re-invest the regained funds in network deployments elsewhere. the government's ultrafast broadband network (UFB) initiative could be described as a 'reverse PPP', where the government initially owns the PPP entity, takes risk and provides seed capital to private-sector partners to build the network, and then eventually sells out to private-sector partners (Tylee, 2013).

The contract signed with Chorus is different in that sense that CFH invests directly in Chorus as a company, but Chorus bears the main risks of the uncertain demand uptake. In return for this government loan, Chorus has to comply with specific coverage and uptake goals, set on milestone dates.

\section{Local initiatives and mixed investment models in Europe}

Before describing the three chosen European cases, a short overview is given of regulations active on the European level. In case a Member State supports the roll-out of broadband by way of an 
equity participation or capital injection into a company that is to carry out the project, it becomes necessary to assess whether this investment will be regarded by the EU as State Aid. In principle, State Aid can play a useful role in cases where the market does not provide sufficient broadband coverage. In general, one could say that state aid (public funding) is not allowed, except in areas where one can prove that the market will not deliver fast broadband (rural and underserved areas). A distinction is made between three general area types (European Commission, 2009):

- The white area refers to an area where NGA networks do not at present exist and where they are not likely to be built in three years. It certainly includes an area where there is no basic broadband infrastructure. It also includes areas where only one basic broadband provider is present or there are several basic broadband providers. However, in the latter case, Member States must prove that the current services are not sufficient to satisfy the needs of citizens and business users and there are no less distortive means.

- The grey areas are areas where only one NGA network is in place or is being deployed in the coming three years. In order to have such State Aid approved by the Commission, Member States must provide evidence that the current or planned NGA network is not sufficient to satisfy the needs of citizens and business users and there are no less distortive means.

- Finally, black areas are areas where more than one NGA network exists in a given area or will be deployed in the coming three years: no subsidies are allowed in this case.

On the other hand, there are two scenarios in which public investment is not regarded as State Aid in accordance with the Case-law of the European Communities ("ECJ"):

1. If the part of the investment that falls under the responsibility of the State can be used (in)directly by an undertaking in circumstances which correspond to normal market conditions, this state investment is not treated as State Aid (basis of the principle of equal treatment within Member States);

2. If a Member State considers the provision of broadband as a service of general economic interest ("SGEI") as qualified by the Altmark ${ }^{1}$ criteria, the State funding cannot be regarded as State Aid (European Commission, 2009).

It is clear that this State Aid regulation contrasts sharply with the government's investment in New Zealand, and thus also affects the FTTH deployment cases.

\subsection{The case of Stokab in Stockholm}

Driven by the incentive to increase the economic attractiveness of the region of Stockholm, the city decided to invest in a FTTH deployment. Stokab, founded in 1994, is a public company, $100 \%$ owned by the city of Stockholm, and was established to deploy a dark fibre access infrastructure to all businesses and households in the Stockholm region. The company was founded as a public infrastructure company (comparable to other public firms responsible for road, railway etc.); all the development, deployment and operations is in direct hands of the company, no outsourcing is done.

\footnotetext{
${ }^{1}$ The four conditions to meet in accordance with the Altmark criteria, as defined to in Article 86(2) of the Treaty of the European Community, are: (a) the beneficiary of a State funding mechanism for an SGEI must be formally entrusted with the provision and discharge of an SGEI, the obligations of which must be clearly defined; (b) the parameters for calculating the compensation must be established beforehand in an objective and transparent manner, to avoid it conferring an economic advantage which may favor the recipient undertaking over competing undertakings; (c) the compensation cannot exceed what is necessary to cover all or part of the costs incurred in the discharge of the SGEI, taking into account the relevant receipts and a reasonable profit for discharging those obligations; and (d) where the beneficiary is not chosen pursuant to a public procurement procedure, the level of compensation granted must be determined on the basis of an analysis of the costs which a typical undertaking, well run, would have incurred in discharging those obligations, taking into account the relevant receipts and a reasonable profit.
} 
As the deployment started before the EU State Aid regulation was established, its public involvement was not questioned.

In its initial phase, the network rollout was financed by publicly-backed loans. As a first goal, the network aimed at connecting mainly public and educational institutions, but was quickly expanded towards private businesses, which requested to be connected on the dark fibre circuits. Although being a public company, taxpayer's money was never used. Instead, the initial €300 million investment was based on loans backed by the city of Stockholm, while the customers' revenues provided the necessary funds for a later expansion of the network. Note that about $50 \%$ of Stokab's revenues flows from direct business customers (e.g. banks, schools, etc) (Broberg, 2012). Stokab reached a breakeven point in 2001, and is now a profitable company, although the majority of their profits is still re-invested in maintenance and further expansion of the network.

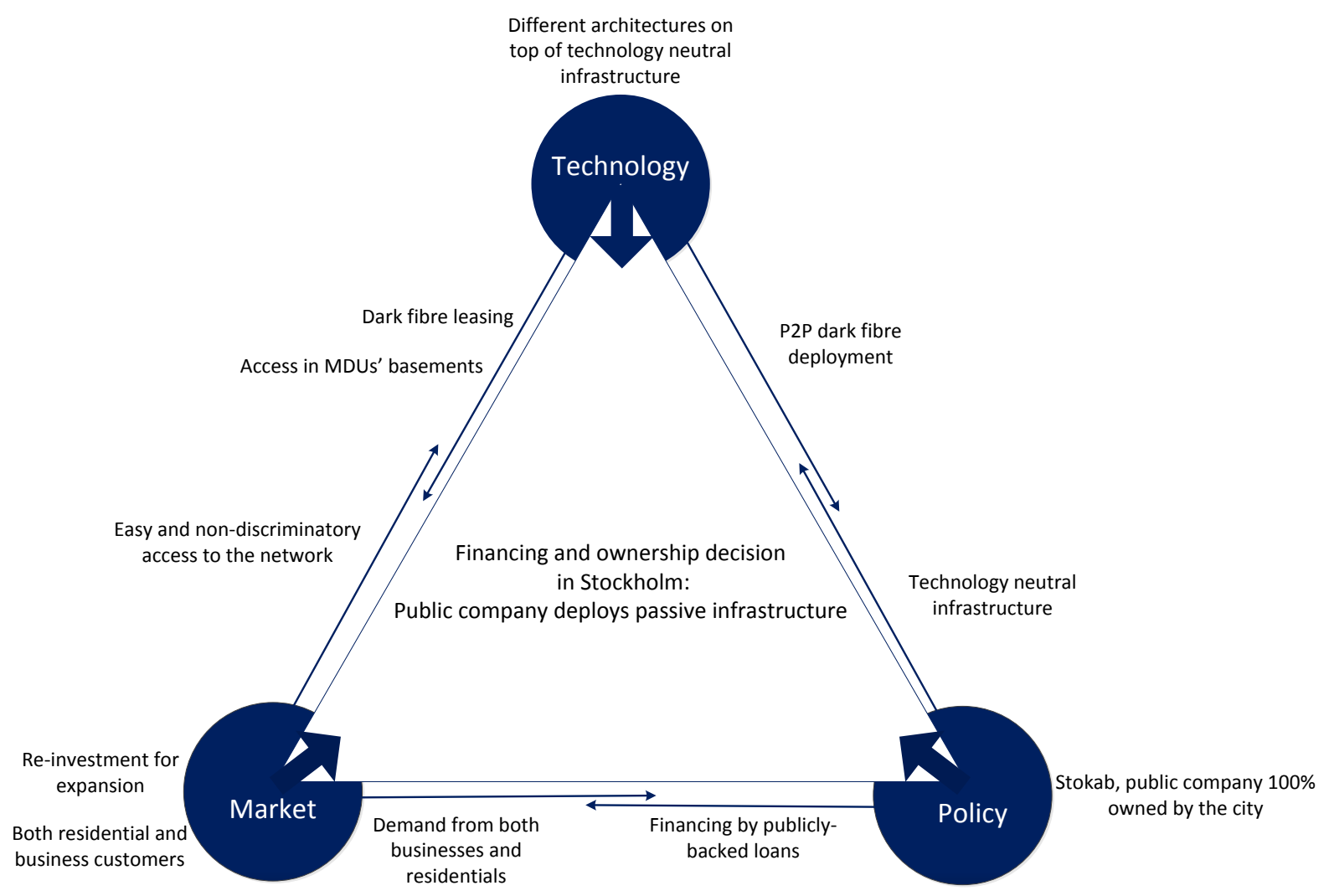

Figure 4: Public deployment in Stockholm, Sweden

As in the first years, the deployment was mainly focused on larger businesses and public buildings, the speed of deployments (in terms of buildings passed) was not very high. The rollout seeded up drastically when the focus shifted to connecting more residential users, in the beginning of the 2000s. In mid-2013, $90 \%$ of households and $100 \%$ of businesses in Stockholm had access to the fibre network. The goal of creating ultrafast reliable connections to the highly knowledge-intensive region that would "meet future communications needs, stimulate competition, promote diversity, offer freedom of choice and minimise the need for excavation" (Stokab, 2014), has definitely been reached. Stockholm is now home to a number of successful international companies (e.g. Skype, Spotify and Transmode), all of which were attracted to the "the most densely fibred city in Europe". 


\subsection{Deployments in the Netherlands: the case of Amsterdam}

Although the FTTH deployment in the Netherlands is now mainly driven by Reggefiber, a passive infrastructure provider set up by an investment company (Reggeborgh), the first Dutch FTTH initiatives were taken by municipalities.

In the case of Amsterdam, the city wanted to explore the importance of high-speed connectivity to the economic well-being of the city, and launched a formal investigation into the best way to proceed. Based on the outcome of several studies with and without the collaboration of the national incumbent, KPN, and the local cable operator, UPC, the municipality decided to create a publicprivate partnership (PPP) to invest in a passive fibre infrastructure. This PPP, GNA (Glasvezelnet Amsterdam BV) was incorporated with three groups of investors - the municipality itself, the housing associations and the private sector - each investing $€ 6$ million in return for a one third stake in the company. Another $€ 12$ million in funding was provided as debt financing, bringing the total investment to $€ 30$ million. Although GNA was taken to court multiple times by the cable operators, the public investment was eventually allowed under the Market Economy Investor Principle:

- All shareholders should invest under the same conditions in a profitable business with an acceptable risk/reward ratio.

- The network should be operated using the 'open network' concept, meaning that the wholesale specifies that all service providers must be able to purchase transport capacity on non-discriminatory conditions.

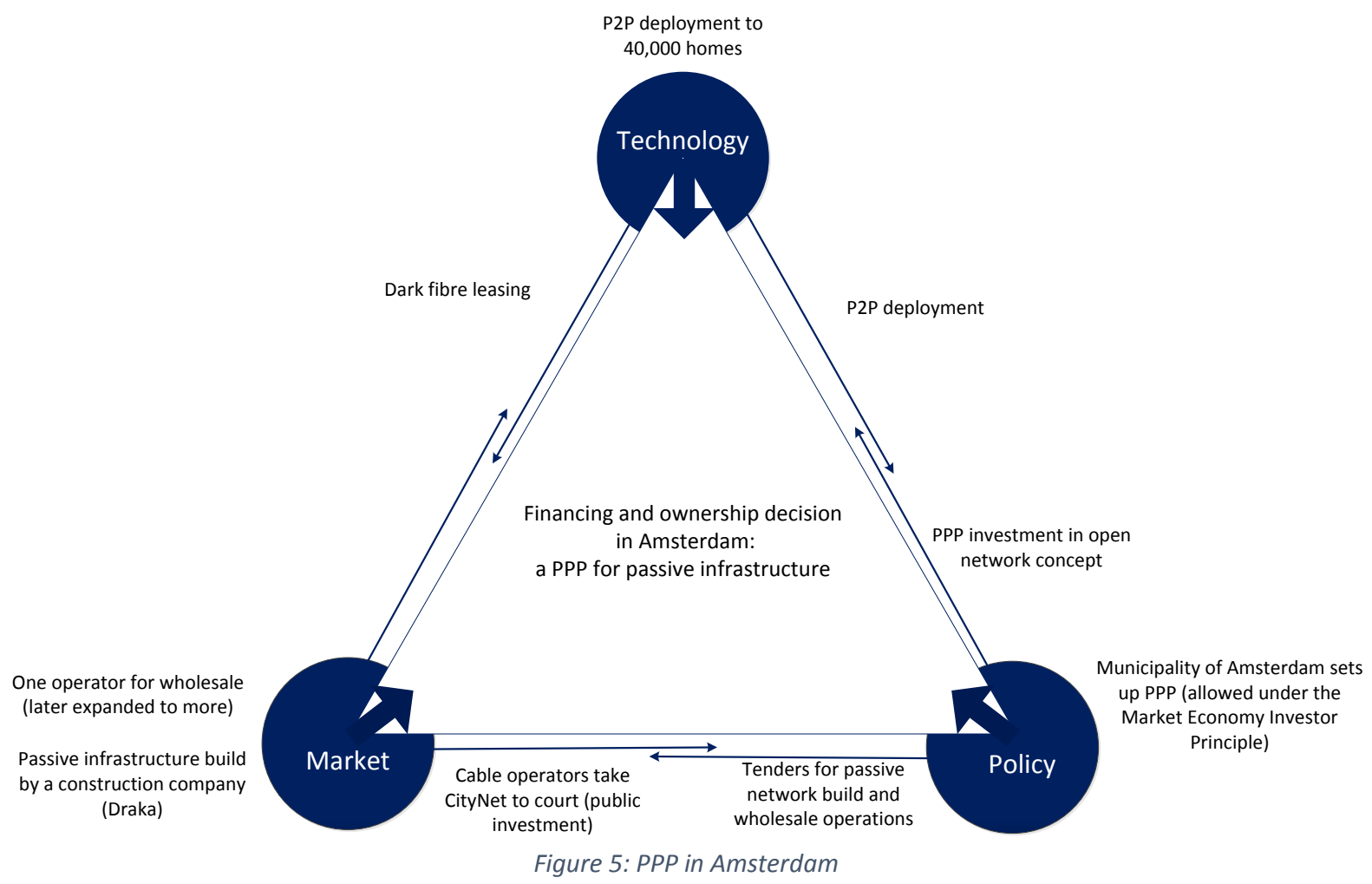

This investment fund of $€ 30$ million was used to cover about 40,000 homes with fibre access, this process took about 2.5 years and finished in February 2009. Then, GNA announced to connect the remaining parts of the city $(420,000$ homes in total) by 2013 , and estimated an overall budget of $€ 300$ million to do so. 
Soon, however, the ownership structure in Amsterdam changed, as Reggefiber (the operator deploying fibre networks in the entire country), has bought about $70 \%$ of the shares, in a partnership with KPN (the Dutch incumbent). The remaining $30 \%$ is still owned by the municipality of Amsterdam. This evolution makes tracking the actual process of the initial project hard, as parts are now integrated with the plans of Reggefiber.

\subsection{Mainly private investment in Portugal}

Although most European FTTH initiatives are based on some form of PPP, exceptional examples of other financing structures can be found. The main example for a pure private investment is to be found in Portugal, where the national incumbent, Portugal Telecom (PT), started a GPON rollout to face the fierce competition by the cable operator which could offer more attractive video-based offers using its HFC network. At the end of 2011, PT had passed 1.6 million homes (FTTH Council, 2011), in comparison to Vodafone Portugal, who has currently covered more than 700,000 homes with FTTH, while aiming for the 1.5 million target by mid-2015 (Vodafone, 2014).

This decision to upgrade to FTTH was helped by the decision of the National Regulatory Authority ANACOM who adopted a segmented regulation after a market analysis in 2008. The decision determined that access to ducts and associated infrastructure (so-called market 4) should be an obligation for all infrastructures (DSL, DOCSIS cable and FTTH), but that a wholesale offer (bitstream access, market 5) should only regulated in non-competitive areas (Figure 6). In areas with sufficient competition (defined as areas where the percentage of passed homes by the main competitor - the cable operator ZON - is larger than 60\%), there is as such no SMP, and according to European guidelines, no need for access regulation (Anacom, 2012). In most of these competitive regions, the combined market shares of ZON and PT currently exceeds $85 \%$.

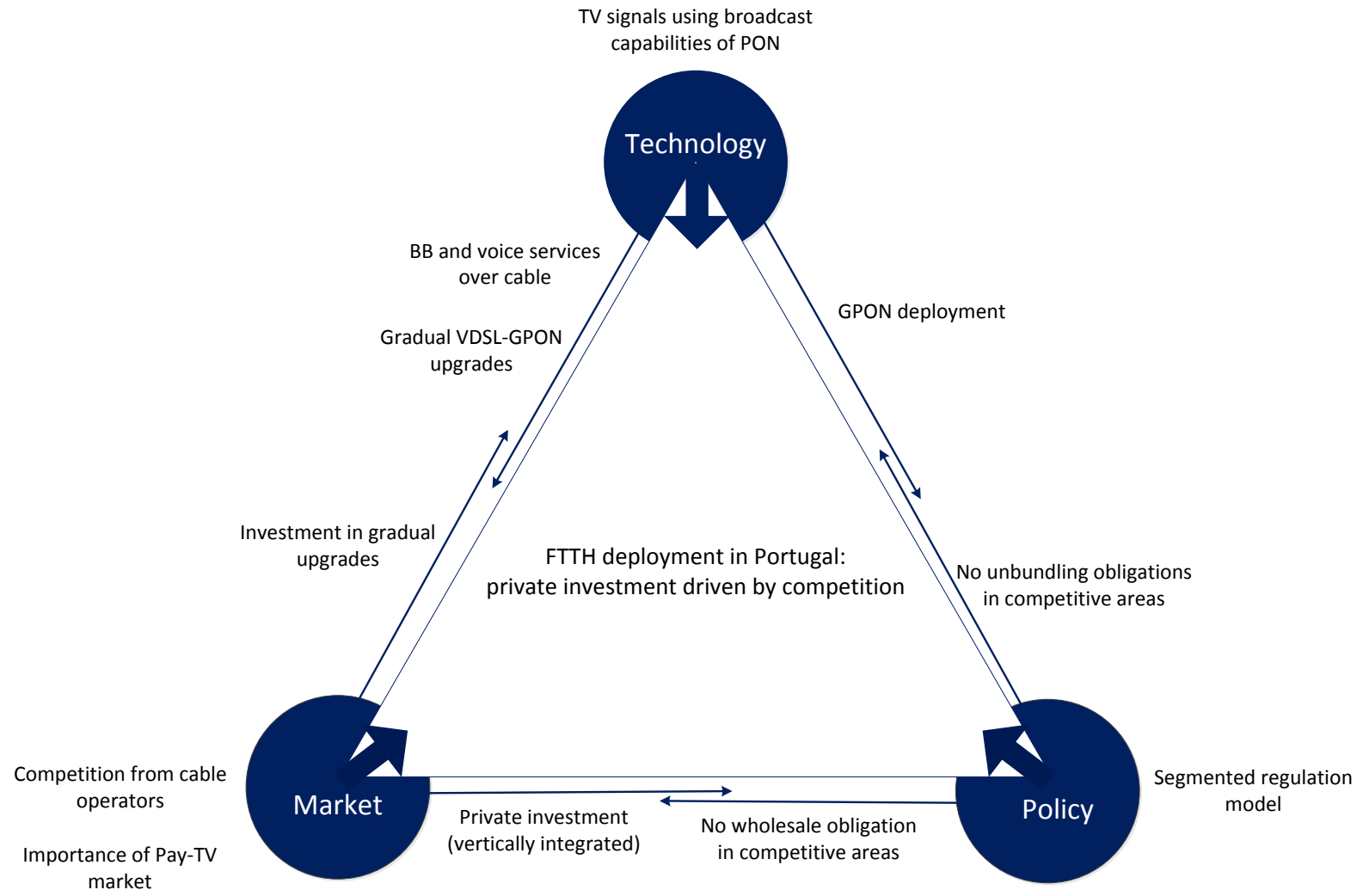

Figure 6: Private investment driven by competition: the case of Portugal Telecom 
The upgrade of Portugal Telecom's network started in 2007 and was a gradual process. First, the network was quickly upgraded to DSL and later the copper loop was shortened by Fibre-to-the-Node installations, with the final step deploying fibre to the actual homes with the GPON technology. The choice for GPON was largely based on its capability for broadcasting, as many Portuguese homes have multiple TV-sets and thus require enough signals (the analogue TV signals could be carried over a third wavelength in the GPON system (RF overlay)).

Installing FTTH furthermore allowed to easily and cost-efficiently upgrade the mobile network to LTE, providing Portugal Telecom with the opportunity of offering quadruple-play for competitive prices.

In other areas of Portugal (the mainly rural, non-competitive areas), the government opened public tenders for the deployment of a wholesale network that would cover $50 \%$ of the targeted population with a minimum download bandwidth of $40 \mathrm{Mbps}$.

\section{Comparison of deployments}

Table 1 summarises the most important decisions in the four cases studied and on the three aspects considered by the framework, each time indicating the sequence of interactions by (a)-(b)-(c). To support the comparison exercise this paper proposes to undertake, Table 1 is complemented with Table 2 which assesses the extent to which the factors chosen as performance indicators have been met. Table 2 displays in two parts: the upper section describes the aspects driving the deployment in each case, particularly what motivates governments to act, while the lower section displays data on construction targets.

Table 1: Overview of the most important impacting decisions on the three pillars of the framework for the different cases

\begin{tabular}{|l|l|l|l|l|}
\hline Decisions & New Zealand & $\begin{array}{l}\text { Stockholm, } \\
\text { Sweden }\end{array}$ & $\begin{array}{l}\text { Amsterdam, } \\
\text { the Netherlands }\end{array}$ & Portugal \\
\hline Policy pillar & $\begin{array}{l}\text { (1) Government } \\
\text { investment }\end{array}$ & $\begin{array}{l}\text { (2) Foundation of } \\
\text { Stokab }\end{array}$ & $\begin{array}{l}\text { (1) Amsterdam City } \\
\text { investment under } \\
\text { market economy } \\
\text { investor principle }\end{array}$ & $\begin{array}{l}\text { (2) No unbundling } \\
\text { obligation }\end{array}$ \\
\hline Market pillar & $\begin{array}{l}\text { (5) Demerger of } \\
\text { Telecom } \\
\text { (2) Wholesale only }\end{array}$ & $\begin{array}{l}\text { (1) Demand from } \\
\text { business users } \\
\text { (3) Dark fibre only }\end{array}$ & $\begin{array}{l}\text { (2) Taken to court by } \\
\text { UPC } \\
\text { (3) Dark fibre only }\end{array}$ & $\begin{array}{l}\text { (1a) Competitive } \\
\text { threat from cable } \\
\text { (1b) Vertical } \\
\text { integration }\end{array}$ \\
\hline Technology & $\begin{array}{l}\text { (3) GPON } \\
\text { deployment } \\
\text { (4) Bitstream } \\
\text { access }\end{array}$ & $\begin{array}{l}\text { (4) Technology-neutral } \\
\text { passive infrastructure }\end{array}$ & $\begin{array}{l}\text { (4) Technology-neutral } \\
\text { passive infrastructure }\end{array}$ & $\begin{array}{l}\text { (3) Gradual upgrade } \\
\text { of DSL network; no } \\
\text { new network } \\
\text { deployment }\end{array}$ \\
\hline
\end{tabular}

Table 2: Factors characterising and indicators comparing the different case studies

\begin{tabular}{|l|l|l|l|l|}
\hline $\begin{array}{l}\text { Factors and } \\
\text { indicators }\end{array}$ & New Zealand & $\begin{array}{l}\text { Stockholm, } \\
\text { Sweden }\end{array}$ & $\begin{array}{l}\text { Amsterdam, } \\
\text { the Netherlands }\end{array}$ & Portugal \\
\hline Initiative & Societal value of BB & Economic & Value of broadband for & PT's response to \\
\hline
\end{tabular}




\begin{tabular}{|c|c|c|c|c|}
\hline drivers & Political incentive & $\begin{array}{l}\text { attractiveness of the } \\
\text { region (businesses) }\end{array}$ & households & $\begin{array}{l}\text { increasing } \\
\text { competition from the } \\
\text { cable operator }\end{array}$ \\
\hline $\begin{array}{l}\text { Investment } \\
\text { mechanism }\end{array}$ & $\begin{array}{l}\text { Public-Private } \\
\text { Partnership }\end{array}$ & $\begin{array}{l}\text { Public ownership and } \\
\text { deployment }\end{array}$ & $\begin{array}{l}\text { Public-Private } \\
\text { Partnership }\end{array}$ & $\begin{array}{l}\text { Private ownership } \\
\text { and deployment }\end{array}$ \\
\hline Risk transfer & $\begin{array}{l}\text { LFCs: private risk } \\
\text { postponed to } \\
\text { operational phase } \\
\text { Chorus: Reduced } \\
\text { private risk by } \\
\text { lump-sum transfer } \\
\text { of government }\end{array}$ & No private risk & $\begin{array}{l}\text { Equal private and } \\
\text { public risk (Market } \\
\text { Economy Investor } \\
\text { Principle) }\end{array}$ & Private risk \\
\hline $\begin{array}{l}\text { Coverage } \\
\text { (achieved) }\end{array}$ & $\begin{array}{l}18 \% \text { of population, } \\
75 \% \text { of priority } \\
\text { users } \\
\text { (Sept } 2013 \text { ) }\end{array}$ & $\begin{array}{l}90 \% \text { of } \mathrm{HH}, 100 \% \text { of } \\
\text { businesses } \\
\text { (May 2013) }\end{array}$ & $\begin{array}{l}\text { 40,000 HH by } 2009 \\
\text { (first project) }\end{array}$ & $\begin{array}{l}2.2 \text { million } \mathrm{HH} \\
\text { (60\% of population) } \\
\text { (Dec } 2012 \text { ) (Anacom, } \\
2013 \text { ) }\end{array}$ \\
\hline $\begin{array}{l}\text { Coverage } \\
\text { (target) }\end{array}$ & $\begin{array}{l}1,340,000 \mathrm{HH}, \\
75 \% \text { of population } \\
\text { mainly urban }\end{array}$ & $\begin{array}{l}450,000 \mathrm{HH} \\
100 \% \text { of Stockholm } \\
\text { (dense) urban }\end{array}$ & $\begin{array}{l}420,000 \mathrm{HH} \\
\text { (dense) urban }\end{array}$ & $\begin{array}{l}\text { Broadband over NGN } \\
\text { to }>50 \% \text { population } \\
\text { by } 2013 \text { (European } \\
\text { Commission, 2011) }\end{array}$ \\
\hline $\begin{array}{l}\text { Speed of } \\
\text { deployment } \\
\text { (relative to } \\
\text { targets) }\end{array}$ & $\begin{array}{l}\text { Faster than target } \\
\text { speed } \\
\text { About } 10 \% \text { of } \\
\text { target per year }\end{array}$ & $\begin{array}{l}\text { No set target speed } \\
\text { About } 5 \% \text { of target per } \\
\text { year (average over a } \\
\text { period of } 20 \text { years) }\end{array}$ & $\begin{array}{l}\text { Slowed down due to } \\
\text { court decisions } \\
\text { First project: about } \\
40 \% \text { of target per year }\end{array}$ & $\begin{array}{l}\text { Faster than target } \\
\text { (already } 10 \% \text { more } \\
\text { HH served than } \\
\text { goals) }\end{array}$ \\
\hline
\end{tabular}

The conclusions that can be drawn from the tables above and the ensued analysis will be discussed in the next paragraphs.

New Zealand's UFB initiative set $75 \%$ as the targeted proportion of households with passing fibre - a similar number found in Portugal, whereas the local city initiatives had much higher targets. It is tempting to state that a nationwide project faces bigger hurdles as the geographic area to cover is much larger than in the citywide cases. In spite of its lower population density (17 people per sq. km (The World Bank, 2014)), and also because of that, New Zealand did not commit to a higher target. The goals set in Portugal also don't include the rural areas, at least not at the present stage. City governments can plan for and target almost all premises, especially in conditions where population density (4,892 and 3,597 people per sq. $\mathrm{km}$ in Stockholm and Amsterdam, respectively (Wikipedia, 2014)) is rather high. An increase in population density leads in general to a decrease in network deployment cost (Van der Wee et al., 2014). It can therefore be stated that the decision of the New Zealand government to only reach $75 \%$ of population was based on a cost-coverage trade-off, one that smaller scale deployment, where the range in cost per home passed is much smaller, did not have to face. On the other hand, a governmental initiative would normally be expected to focus more on universal coverage, thereby making sure all households are offered the ability to connect. In the case of New Zealand, the Rural Broadband Initiative - a complementary deployment to UFB targets this goal, albeit using cheaper (VDSL and fixed-wireless) solutions. 
In terms of the speed of deployment, New Zealand's CFH does not report any delays in the aggregate level; however, the controversy arising from regulatory decisions on the price of unbundled copper lines may impact the speed with which Chorus is deploying the fibre connections, especially in the largest populated areas. In Amsterdam, the cable (DOCSIS) operator took the municipality's investment plan to court, because it was said to distort a well-functioning market. Although granted in the end, these court processes delayed the entire project significantly, and as such had a massive impact on the termination dates. In Stockholm, the initial network deployment was not set at a target speed of deployment, but was rather adjusted to market demand. Now that the network is operational and mature, targets are being set to connect the remainder of the homes. One could conclude that public involvement (and pressure) leads to an on- or above-target speed of deployment, but that regulatory uncertainties could delay the progress. In the case of Portugal, targets are more than met, and before target date, but as private operators not always disclose their goals, it is difficult to draw robust conclusions here.

Evaluating the links between investment mechanism, initiative drivers and risk transfers reveals a strong relationship between a societal driver and the investment of public money. In both New Zealand and Amsterdam, the drivers followed the results of reports denoting the importance of broadband to society (Amsterdam, 2002; The New Zealand Institute, 2007), and in both cases, a PPP with significant private risk (equal private/public risk in Amsterdam) was used as an investment vehicle. In Stockholm, the city reacted to a request from businesses to be connected on a very highspeed, technology-neutral network. The investment here was fully public (publicly-backed loans) but the deploying company, Stokab, was set up to achieve return on investment rather quickly. In Portugal, finally, the driver was set by the market (emerging competition), and hence, the reaction to invest was also fully private. It can be concluded that a market driver (competition) is answered by a market response, while a societal driver is used by the policy pillar to take the initiative.

In the choice for either a purely public or PPP investment decision the link to the driver is less clear. Here, a significant influence of the regulatory force in the policy pillar can be identified. For example, in the case of Amsterdam, purely public investment was not allowed, whereas alignment of the investment and sharing of the risk was a necessary condition for public involvement. One can tentatively conclude that the driver is crucial for the choice of investment mechanism, but the magnitude of public involvement is largely defined by regulatory rules.

How the network is actually deployed and services are offered (technological pillar) is also impacted by the market and policy pillar, as the cases show. A publicly backed network deployment obliges in all cases an open access network to be deployed, albeit on different layers. In all three cases (Stockholm, Amsterdam and New Zealand), the company or companies deploying the network cannot offer services directly to residential end-customers, but lease access (on a dark fibre or bitstream layer) to service providers, who then trade with end-users. In Portugal, the situation is completely different: not only is Portugal Telecom operating as a service provider as well (no open access), they are fully vertically integrated, so don't even have to unbundle their network. Considering the topology deployed (P2P or P2MP), it is harder to draw conclusions about impacting factors from the policy or market side. In general, open access is easier to be offered on a P2P network (one dedicated fibre per end-user is available), and therefore public parties tend to support P2P deployment more. In New Zealand however, cost considerations changed this initial idea 
towards a GPON deployment with a limited percentage of P2P access that should be granted upon request.

Of course, this topology decision also impacts the amount of risk incurred, as deploying P2P is more expensive, but does not generate significantly higher revenues from most (residential) users. A link can thus be found between the deployment decision and the investment mechanism. On the other hand, P2P allows for easy dark fibre access, which was a crucial factor in the topology decision in Stockholm, as up to $50 \%$ of Stokab's revenue comes from business customers (banks, media companies, etc.), who lease dark fibre directly (without passing by a service provider).

\section{Conclusions and recommendations}

Although is it generally recognised that the next step in broadband networks is the evolution to NGA and more specifically FTTH networks, the investment required to actually deploy these networks is regarded as too high by many current telecom operators. As the importance of fast and reliable broadband to society and economic growth has been proven, more and more public actors decide to help out by investing in NGA networks, though their plans are frequently constrained by regulatory norms.

This paper studied the investment mechanisms used in different FTTH deployment cases, with a focus on Public-Private Partnerships, by investigating the technology, policy and market interactions, and evaluates the success of the deployment in terms of deployment speed and coverage.

In general, our analysis showed the importance of the policy pillar in all types of deployment, be it as full investment, participation in a PPP or indirect aid in the form of regulatory holidays. The policy pillar furthermore showed to impact the technological pillar significantly, in obliging open access on a dark fibre (P2P topology) or bitstream (P2MP topology - GPON architecture) layer. The impact of the market pillar is limited in case of a public investment or PPP, but significant in the case of a private deployment, as there, the competitive threat provided a driver for investment. In all cases, the initiative lies with the policy or market pillar, and the technology pillar follows. In cases where the market takes the initiative, the technology pillar is less restricted than in policy-led cases.

The coverage targets are higher (in percentage of households) in smaller-scale deployments, as the range of cost per home passed is smaller and as such provides for easier planning. Although it could be expected that a government-driven deployment would target $100 \%$ of population (as to cancel out the digital divide), cost-coverage trade-offs have reduced this target, at least for FTTH coverage. In terms of speed of deployment, publicly-backed initiatives tend to achieve on or above targets.

Although the described cases here follow different approaches, Public-Private Partnerships are identified as the most followed option, as private initiatives similar to the one in Portugal are not likely to be taken in many places in the near future. The main advantage of a PPP is probably that it combines the strengths and goals of public and private players. Public players reduce the risk for private players, and at the mean time make sure that the offers that are put on the market are fair and reasonable. Private players see a more reliable business case, but are still driven to employ their technical knowledge strengths to the maximum in order to minimize their own risk and ensuring sufficient return on investment. 
Evaluating the success of NGA and FTTH deployments of course goes beyond assessing the coverage and speed of deployment. The work in this paper could be further extended towards including other evaluation characteristics, to fully investigate the efficiency and effectiveness of the cases. Effectiveness denotes whether the set goals are reached, and can span characteristics ranging from target coverage and speed of deployment, to uptake and envisaged return on investment. Efficiency measures the way the goals were reached, which includes budget evaluation and operational monitoring.

\section{Acknowledgment}

The first author received funding from the Agency for Innovation by Science and Technology in Flanders, Belgium. The authors want to acknowledge the support of CODE, the Centre of the Digital Enterprise at the University of Auckland.

\section{References}

Amsterdam (2002). Beleidsissues ten aanzien van 'glas-naar-de-meterkast'. Retrieved from CityNet Amsterdam. Available at: http://www.citynet.nl/upload/Adam\%20the\%20big\%20cherry\%20\%20eindrapport_1.pdf

Anacom (2012). Mercados grossistas de acesso à infraestrutura de rede num local fixo e de acesso em banda larga (in Portuguese). Available at: http://www.anacom.pt/streaming/mercados4_5_ consulta_15022012.pdf?contentld=1116435\&field=ATTACHED_FILE

Anacom (2013). Report on Regulation, Supervision and Other Activities 2012 (page 24). Available at: http://www.anacom.pt/render.jsp?contentld=1184395\&languageld=1

Beltrán, F. (2012). Open access networks and national broadband plans: Tales from Down Under. ITS World conference, Bangkok, Thailand, November 2012.

Beltrán, F. (2013). Effectiveness and Efficiency in the Build-Up of High-Speed Broadband Platforms in Australia and New Zealand. Communications \& Strategies, (91).

Broberg, A. (2012). Challenges for an open physical infrastructure provider. ECOC Conference, Amsterdam, The Netherlands, September 2012.

Cave, M. (2012). Regulating the price of copper in New Zealand. Submission to the Commerce Commission on the Revised Draft Determination on the Benchmarking Review for the Unbundled Copper Local Loop Service, 1 June 2012.

Crown Fibre Holdings (2013). Ultra-Fast Broadband for New Zealanders. Website. Accessed 20-112013 from http://www.crownfibre.govt.nz/.

European Commission (2009). Commission Communication 2009/C 235/04: Community Guidelines for the application of State aid rules in relation to rapid deployment of broadband networks.

European Commission (2011). State aid SA.30317 - Portugal - High-speed broadband in Portugal. Available at: http://ec.europa.eu/competition/state_aid/cases/236635/236635_1199063_71_2. pdf

Falch, M., \& Henten, A. (2010). Public private partnerships as a tool for stimulating investments in broadband. Telecommunications Policy, 34(9), 496-504.

FTTH Council (2011). Portugal Telecom. Incumbent gains competitive advantage with FTTH. FTTH Council Case study. Available at: http://www.ftthcouncil.eu/documents/CaseStudies/ PORTUGAL_TELECOM_Update1.pdf

Fourie, F. and Burger, P. (2000). An economic analysis and assessment of public-private partnerships (PPPs). The South African Journal of Economics, 68(4). 
Howell, B. (2013). Mediating on Market Mechanisms. Competition and Regulation Times, November 2013.

Kim, Y., Kelly, T. \& Raja, S. (2009). Building broadband Strategies and policies for the developing world. Global Information and Communication Technologies (GICT) Department. World Bank.

Lemstra, W. \& J. P. M. Groenewegen (2009). Markets and public values - The potential effects of Private Equity Leveraged Buyouts on the safeguarding of public values in the telecommunications sector. Delft, The Netherlands: TUDelft.

Melody, W.H. (2013). Open standards: A shrinking public space in the future network economy? ITU Kaleidoscope: Building Sustainable Communities (K-2013).

OECD. (2008). Public-Private Partnerships, in pursuit of risk sharing and value for money. Available from: http://www.oecd.org/governance/budgeting/public-privatepartnershipsinpursuitofrisk sharingandvalueformoney.htm

OECD (2009). The role of communication infrastructure investment in economic recovery. Available from: http://www.oecd.org/internet/broadbandandtelecom/42799709.pdf

Sadowski, B., Howell, B., \& Nucciarelli, A. (2013). Structural Separation and the Role of Public-Private Partnerships in New Zealand's UFB Initiative. Communications \& Strategies, (91).

Stokab (2014). This is Stokab. Last accessed 2014-03-14 from http://www.stokab.se/In-english/

The New Zealand institute (2008) Delivering on the broadband aspiration: a recommended pathway to fibre for New Zealand. Available at: http://nzinitiative.org.nz/site/nzbr/files/ Delivering_on_the_broadband_aspiration.pdf

The World Bank (2014). Population density (people per sq. km of land area). Accessed 21-05-2014 at http://data.worldbank.org/indicator/EN.POP.DNST?order=wbapi_data_value_2012+wbapi_data_v alue+wbapi_data_value-last\&sort=desc.

Tylee, D. (2013). ISCR conference. A participant's perspective. Competition and Regulation Times, November 2013.

Van der Wee, M. et al. (2014a). Identifying and quantifying the indirect benefits of broadband networks for e-government and e-business: A bottom-up approach. Telecommunications Policy, 5(14).

Van der Wee, M. et al. (2014). Evaluation of the Techno-Economic Viability of Point-to-Point Dark Fiber Access Infrastructure in Europe. Journal of Optical Communication Networks (6), 238-249.

Vodafone (2014). News release: Vodafone wins award for its rollout of fibre in Europe. Available at http://www.vodafone.com/content/index/media/vodafone-group-releases/2014/award-fibrerollout.html

Wikipedia (2014). Population density of European cities. Available at http://en.wikipedia.org/wiki/List_of_European_Union_cities_proper_by_population_density 